Article

\title{
Phosphorus and Zinc Fertilization Influence Crop Growth Rates and Total Biomass of Coarse vs. Fine Types Rice Cultivars
}

\author{
Amanullah 1,*D, Inamullah ${ }^{2}$, Jawaher Alkahtani ${ }^{3}$, Mohamed Soliman Elshikh ${ }^{3}$, \\ Mona S. Alwahibi ${ }^{3} \mathbb{D}$, Asim Muhammad $^{1}{ }^{\mathbb{D}}$, Manzoor Ahmad $^{4} \mathbb{D}$ and Shah Khalid ${ }^{1}$ \\ 1 Department of Agronomy, Faculty of Crop Production, The University of Agriculture, \\ Peshawar 25130, Pakistan; asimmuh@aup.edu.pk (A.M.); khalidmashaal@aup.edu.pk (S.K.) \\ 2 Agriculture Extension Swabi, Khyber Pakhtunkhwa 23020, Pakistan; inamullah@aup.edu.pk \\ 3 Department of Botany and Microbiology, College of Science, King Saud University, \\ Riyadh 11451, Saudi Arabia; jsalqahtani@ksu.edu.sa (J.A.); melshikh@ksu.edu.sa (M.S.E.); \\ malwhibi@ksu.edu.sa (M.S.A.) \\ 4 Department of Agriculture, Bacha Khan University, Charsadda 24461, Pakistan; drmanzoor@bkuc.edu.pk \\ * Correspondence: amanullah@aup.edu.pk; Tel.: +92-300-574-1363
}

Received: 24 July 2020; Accepted: 7 September 2020; Published: 9 September 2020

\begin{abstract}
Under the rice-wheat cropping system (RWS), the continuous cropping of rice (Oryza sativa L.) and wheat (Triticum aestivum L.) deplete soil fertility, and reduce crop growth and total rice biomass. In RWS, both phosphorus ( $\mathrm{P}$ ) and zinc ( $\mathrm{Zn}$ ) deficiencies are considered important nutritional constraints for reducing rice crop growth rates (CGR) and total biomass/biological yield (BY). The objective of this experiment was to investigate the impact of phosphorus $\left(0,40,80,120 \mathrm{~kg} \mathrm{P} \mathrm{ha}^{-1}\right)$ and zinc rates $\left(0,5,10,15 \mathrm{~kg} \mathrm{Zn} \mathrm{ha}^{-1}\right)$ on CGR and BY of three rice genotypes [fine (Bamati-385) versus coarse (Fakhre-e-Malakand and Pukhraj)] in Northwestern Pakistan during summer 2011 (Y1) and 2012 (Y2). The results revealed that higher CGR at various growth stages and total BY was obtained with the integrated use of higher phosphorus (80 and $\left.120 \mathrm{~kg} \mathrm{P} \mathrm{ha}^{-1}\right)$ and zinc rates (10 and $\left.15 \mathrm{~kg} \mathrm{Zn} \mathrm{ha}{ }^{-1}\right)$. The lower CGR and BY were recorded when P and Zn were not applied (control) or when P and Zn were applied alone. In the case of rice genotypes, the highest CGR and BY were recorded for the hybrid rice (Pukhraj) than the other two genotypes. The CGR was increased to the highest level at the heading stage as compared to tillering and physiological maturity. The increase in CGR had a positive impact on the total BY of rice cultivars. The increase in BY had a positive relationship with grain yield and grower's income. It was concluded from the study that the combined application of higher $\mathrm{P}$ and $\mathrm{Zn}$ rates to the coarse rice genotypes (Fakhre-e-Malakand and Pukhraj) could increase CGR, total BY, crop productivity and profitability.
\end{abstract}

Keywords: Oryza sativa L.; genotypes; phosphorus; zinc; crop growth rate; BY

\section{Introduction}

Rice (Oryza sativa L.) is the staple food of mankind and provides 35\% 60\% of the dietary calories consumed by 3 billion people, making it—without question—the most important crop worldwide [1]. The demand for increasing rice production is particularly urgent, because the population of traditional rice-producing countries will require $70 \%$ more rice by the year 2025 [2,3]. Hence, world rice production must increase by approximately $1 \%$ annually to meet the growing demand [4].

Phosphorus $(\mathrm{P})$ and zinc $(\mathrm{Zn})$ deficiency are two of the most important nutritional constraints to rice growth across the globe [2,5-7]. Phosphorus and zinc deficiency not only decrease the productivity and quality of the current rice crop [2,5] but also have a negative impact on the productivity of the 
subsequent wheat crop under the rice-wheat cropping system (RWS) $[8,9]$. Zinc is absorbed by plants as cations $\left(\mathrm{Zn}^{2+}\right)$ and $\mathrm{P}$ is taken up by plants as phosphate anions $\left(\mathrm{H}_{2} \mathrm{PO}_{4}{ }^{-1}\right.$ or $\left.\mathrm{HPO}_{4}{ }^{-2}\right)$. These cations and anions attract each other, which facilitates the formation of chemical bonds that can form within the soil or the plant. If excess $\mathrm{P}$ binds a large quantity of $\mathrm{Zn}$ normally available to the plant, the result can be a P-induced $\mathrm{Zn}$ deficiency [9]. This generally results in reduced shoot $\mathrm{Zn}$ concentration and reduced rice growth $[6,10]$.

Fertilizers are a costly input, such that their use limits the profitability of rice farming for high-input or low-input systems, and the use of fertilizers for these two rice nutrients is notoriously inefficient [11]. Regarding the interaction of $\mathrm{Zn}$ and $\mathrm{P}$, numerous studies have been carried out and all confirm this point, that $\mathrm{Zn}$ and $\mathrm{P}$ imbalance in the plant, as a result of excessive accumulation of $\mathrm{P}$, causes $\mathrm{Zn}$ imposed deficiency [12-16]. Next to $\mathrm{N}$ and $\mathrm{P}$ deficiency, $\mathrm{Zn}$ deficiency is now considered the most widespread nutrient disorder in lowland rice $[17,18]$. High soil $\mathrm{pH}$ appears to be the main factor associated with the widespread $\mathrm{Zn}$ deficiency in the calcareous soils of the Indo-Gangetic plains of India and Pakistan $[19,20]$. The yield of rice is an integrated result of various processes, including canopy photosynthesis, conversion of assimilates to biomass and partitioning of assimilates to grains $[6,7,21-23]$.

Studies on $\mathrm{Zn}$ and $\mathrm{P}$ interaction and their impact on rice crop growth rates (CGR) and total biomass/biological yield (BY) have not been reported, even under RWS. The main objective of this experiment was to investigate whether there is any difference in the CGR and BY of rice genotypes at various $\mathrm{P}$ and $\mathrm{Zn}$ rates.

\section{Materials and Methods}

\subsection{Site Description}

A field experiment was conducted to investigate the impact of phosphorus $\left(0,40,80,120 \mathrm{~kg} \mathrm{P} \mathrm{ha}^{-1}\right)$ and zinc rates $\left(0,5,10,15 \mathrm{~kg} \mathrm{Zn} \mathrm{ha}^{-1}\right)$ on the crop growth rate (CGR) and total biomass/biological yield (BY) of three rice (Oryza sativa L.) genotypes [fine (Bamati-385) versus coarse (Fakhre-e-Malakand and Pukhraj)] under RWS. The experiment was conducted at Batkhela, Malakand Agency on farmer's field in Northwest Pakistan during 2011 (Y1) and 2012 (Y2). Batkhela is located at $34^{\circ} 37^{\prime} 0^{\prime \prime} \mathrm{N}$ and $71^{\circ} 58^{\prime} 17^{\prime \prime} \mathrm{E}$ in DMS (Degrees Minutes Seconds) or 34.6167 and 71.9714 (in decimal degrees). The soil of the experimental site is clay loam, slightly alkaline in reaction $(\mathrm{pH}=7.3)$, non-saline $\left(\mathrm{ECe}=1.02 \mathrm{dS} \mathrm{m}^{-1}\right)$, moderately calcareous in nature $\left(\mathrm{CaCO}_{3}=7.18 \%\right)$, low in soil fertility containing less organic matter $(0.71 \%)$, extractable $\mathrm{P}\left(5.24 \mathrm{mg} \mathrm{kg}^{-1}\right)$ and $\mathrm{Zn}\left(0.93 \mathrm{mg} \mathrm{kg}^{-1}\right)[9,24]$. Weather data for RWS during the two years, e.g., 2011-2012 (Y1) and 2012-2013 (Y2) were different [9].

\subsection{Experimentation}

The experiment was conducted in a randomized complete block design with a split-plot arrangement using three replications. Combination of factor- $\mathrm{A}$, three rice genotypes [fine (Bamati-385) versus coarse (Fakhre-e-Malakand and Pukhraj)] and factor-B, four P rates $\left(0,40,80,120 \mathrm{~kg} \mathrm{P} \mathrm{ha}^{-1}\right.$ ) were allotted to main plots, while factor-C, the four $\mathrm{Zn}$ rates $\left(0,5,10,15 \mathrm{~kg} \mathrm{Zn} \mathrm{ha}^{-1}\right)$ were allotted to subplots. A sub-plot size of $12 \mathrm{~m}^{2}(3 \mathrm{~m} \times 4 \mathrm{~m})$ having 300 hills per subplot, and hill to hill distance of $20 \mathrm{~cm}$ apart was used. A uniform dose of $120 \mathrm{~kg} \mathrm{~N} \mathrm{ha}^{-1}$ as urea and $60 \mathrm{~kg} \mathrm{~K}_{2} \mathrm{O} \mathrm{ha}^{-1}$ [SOP (sulphate of potash) or MOP (muriate of potash)] was applied to all treatments. All potassium, P (triple super phosphate) and $\mathrm{Zn}$ (zinc sulphate) were applied at the time of transplanting, while nitrogen was applied in two equal splits, i.e., $50 \%$ each at transplanting and 30 days after transplanting. The amount of sulfur was maintained constantly in the $\mathrm{Zn}$ applied plots by adding additional sulfur using SOP. All subplots were separated by about $30 \mathrm{~cm}$ ridges to stop the movement of water/nutrients among different treatments. Water to each treatment was separately applied from the water channel and the crop was grown under flooded condition almost the whole growing period [24]. 
Data were calculated on CGR at three different growth stages (tillering, heading and physiological maturity) and total BY at harvesting. At tillering, heading and physiological maturity five hills within each treatment were harvested. Leaf, stems and panicles were separated, dried and weighed by an electronic balance to record data on dry weight of leaf, stem, and panicles (no panicles were observed at tillering). Dry weight hill ${ }^{-1}$ at each growth stage was calculated as sum of the dry weights of the plant components [24]. The CGR is defined as dry matter accumulation per unit ground area per unit time was determined at various growth stages (transplanting to tillering, tillering to heading, and heading to physiological maturity) according to the procedures used by [25].

$$
C G R=W_{2}-W_{1} /(\mathrm{GA})\left(t_{2}-t_{1}\right) \ldots \ldots \ldots \ldots \ldots \ldots\left(\mathrm{g} \mathrm{m}^{-2} \text { day }^{-1}\right)
$$

where

$W_{1}=$ Dry weight $(\mathrm{g}) \mathrm{m}^{-2}$ at the beginning of interval;

$W_{2}=$ Dry weight $(\mathrm{g}) \mathrm{m}^{-2}$ at the end of the interval;

$t_{2}-t_{1}=$ The time interval between the two consecutive samplings;

$G A=$ Ground area occupied by plants at each sampling.

At harvest maturity, four meters square area within each treatment was harvested, the material was sun-dried up to constant weight and weighed, and then was converted into BY $\left(\mathrm{kg} \mathrm{ha}^{-1}\right)$.

\subsection{Statistical Analysis}

Data were subjected to analysis of variance (Table 1) according to the methods described for randomized complete block design with split plot arrangement combined over the years [26] and means between treatments were compared using least significant difference (LSD) test $(p \leq 0.05)$.

Table 1. Mean square and significance level for crop growth rates (CGR) and biomass/biological yield (BY) of rice genotypes (G) as affected by phosphorus (P) and zinc (Zn) application.

\begin{tabular}{|c|c|c|c|c|c|c|c|c|c|}
\hline \multirow{2}{*}{ Source of Variance } & \multirow{2}{*}{ DF } & \multicolumn{2}{|c|}{ CGR T-T } & \multicolumn{2}{|c|}{ CGR T-H } & \multicolumn{2}{|c|}{ CGR H-PM } & \multicolumn{2}{|c|}{ BY } \\
\hline & & MS & Sig. & MS & Sig. & MS & Sig. & MS & Sig. \\
\hline Years (Y) & 1 & 75.8 & $* *$ & 7410 & $* * *$ & 245.4 & ns & $56,603,277$ & ns \\
\hline Rep. (within years) & 4 & - & - & - & - & - & - & - & - \\
\hline Genotypes & 2 & 70.0 & $* * *$ & 9169 & $* * *$ & 2636 & $* * *$ & $44,688,057$ & $* * *$ \\
\hline$Y \times G$ & 2 & 8.69 & $* *$ & 1139 & $* * *$ & 1676 & $* * *$ & $3,416,454$ & ns \\
\hline Phosphorus (P) & 3 & 58.5 & $* * *$ & 4646 & $* * *$ & 596.0 & $* * *$ & $85,343,094$ & $* * *$ \\
\hline $\mathrm{Y} \times \mathrm{P}$ & 3 & 4.20 & ns & 217 & ns & 52.43 & ns & $9,035,611$ & ns \\
\hline$P \times G$ & 6 & 3.00 & $*$ & 65.9 & $* * *$ & 92.01 & ns & $28,039,619$ & $* * *$ \\
\hline $\mathrm{Y} \times \mathrm{P} \times \mathrm{G}$ & 6 & 6.71 & $* * *$ & 11.1 & ns & 25.56 & ns & $1,125,688$ & ns \\
\hline Pooled Error-I & 44 & 1.18 & - & 11.5 & - & 46.16 & - & $3,999,861$ & - \\
\hline Zinc (Zn) & 3 & 7.56 & $* * *$ & 202 & $* * *$ & 166.2 & * & $23,002,115$ & $* * *$ \\
\hline $\mathrm{Y} \times \mathrm{Zn}$ & 3 & 1.70 & ns & 1.53 & ns & 12.19 & ns & 356,618 & ns \\
\hline $\mathrm{Zn} \times \mathrm{G}$ & 6 & 0.94 & ns & 4.28 & ns & 6.53 & ns & $2,206,022$ & ns \\
\hline $\mathrm{Y} \times \mathrm{Zn} \times \mathrm{G}$ & 6 & 0.49 & ns & 39.5 & $* * *$ & 21.26 & ns & $1,123,908$ & ns \\
\hline $\mathrm{P} \times \mathrm{Zn}$ & 9 & 1.02 & ns & 10.2 & ns & 60.06 & ns & $2,855,133$ & ns \\
\hline $\mathrm{Y} \times \mathrm{P} \times \mathrm{Zn}$ & 9 & 2.18 & $* *$ & 7.68 & ns & 41.47 & ns & 985,953 & ns \\
\hline $\mathrm{P} \times \mathrm{Zn} \times \mathrm{G}$ & 18 & 1.82 & $* * *$ & 14.1 & $*$ & 39.70 & ns & $5,048,345$ & $* *$ \\
\hline $\mathrm{Y} \times \mathrm{P} \times \mathrm{Zn} \times \mathrm{G}$ & 18 & 1.39 & $* *$ & 13.5 & * & 58.82 & ns & $1,417,858$ & ns \\
\hline Pooled Error-II & 144 & 0.67 & - & 7.85 & - & 42.91 & - & $2,149,826$ & - \\
\hline Total & 287 & - & - & - & - & - & - & - & - \\
\hline CV main plots $(\%)$ & & 15.1 & & 8.6 & & 19.4 & & 11.0 & \\
\hline CV sub plots (\%) & & 11.4 & & 7.1 & & 18.0 & & 8.0 & \\
\hline
\end{tabular}

Where: MS stands for mean square, Sig. for significance, ns for non-significant, while ${ }^{*}{ }^{* *}$ and ${ }^{* * *}$ stands for significant at 5,1 and $0.1 \%$ level of probability, respectively. $\mathrm{T}-\mathrm{T}=$ transplanting to tillering, $\mathrm{T}-\mathrm{H}=$ tillering to heading, and $\mathrm{H}-\mathrm{PM}=$ heading to physiological maturity. 


\section{Results}

\subsection{Crop Growth Rate from Transplanting to Tillering}

Crop growth rate (CGR) $\left(\mathrm{g} \mathrm{m}^{-2}\right.$ day $\left.^{-1}\right)$ at the early growth stage (tillering) was significantly affected by $\mathrm{P}$ and $\mathrm{Zn}$ rates, genotypes and years (Table 1). The interactions $\mathrm{Y} \times \mathrm{G}, \mathrm{P} \times \mathrm{G}$ and $\mathrm{P} \times \mathrm{Zn} \times \mathrm{G}$ were also significant for CGR (Table 1). Years mean data indicated that the highest CGR $\left(7.92 \mathrm{~g} \mathrm{~m}^{-2}\right.$ day $\left.^{-1}\right)$ was associated with $120 \mathrm{~kg} \mathrm{P} \mathrm{ha}^{-1}$, being at par with $80 \mathrm{~kg} \mathrm{P} \mathrm{ha}^{-1}\left(7.77 \mathrm{~g} \mathrm{~m}^{-2} \mathrm{day}^{-1}\right)$, and minimum CGR (5.96 $\mathrm{g} \mathrm{m}^{-2} \mathrm{day}^{-1}$ ) was calculated for P control plots (Table 2). In the case of $\mathrm{Zn}$ rates, maximum CGR (7.41 $\mathrm{g} \mathrm{m}^{-2}$ day $^{-1}$ ) was recorded with $15 \mathrm{~kg} \mathrm{Zn} \mathrm{ha}^{-1}$ being statistically identical with 5 and $10 \mathrm{~kg} \mathrm{Zn} \mathrm{ha}^{-1}$, and the $\mathrm{Zn}$ control plots had reduced CGR to a minimum level $\left(6.69 \mathrm{~g} \mathrm{~m}^{-2} \mathrm{day}^{-1}\right)$. Among the three rice genotypes, maximum CGR $\left(8.12 \mathrm{~g} \mathrm{~m}^{-2} \mathrm{day}^{-1}\right)$ was recorded for Pukhraj, followed by F-Malakand $\left(6.84 \mathrm{~g} \mathrm{~m}^{-2}\right.$ day $\left.^{-1}\right)$, while minimum CGR $\left(6.50 \mathrm{~g} \mathrm{~m}^{-2} \mathrm{day}^{-1}\right)$ was recorded for fine genotype (B-385).

The $Y \times G$ interaction (Table 2) indicated that CGR for all three genotypes was higher in $Y 2$ than in Y1. The Y2 had higher CGR $\left(7.67 \mathrm{~g} \mathrm{~m}^{-2}\right.$ day $\left.^{-1}\right)$ as compared with Y1 $\left(6.64 \mathrm{~g} \mathrm{~m}^{-2}\right.$ day $\left.^{-1}\right)$. The P $\times \mathrm{G}$ interaction indicated that CGR of all three rice genotypes was increased while increasing the $\mathrm{P}$ level (Figure 1) and the increase was higher for the two coarse genotypes (Pukhraj and F-Malakand) than fine genotype (B-385). The three-way interaction among $\mathrm{P} \times \mathrm{Zn} \times \mathrm{G}$ indicated that the CGR for all three rice genotypes was increased while increasing $\mathrm{P}$ and $\mathrm{Zn}$ rates (Figure 2), and both coarse genotypes (Pukhraj and F-Malakand) had higher CGR than fine genotype (B-385) at all P and Zn rates.

Table 2. Crop growth rate $\left(\mathrm{g} \mathrm{m}^{-2} \mathrm{day}^{-1}\right)$ from transplanting to tillering of rice genotypes as affected by phosphorus and zinc application.

\begin{tabular}{lccc}
\hline & \multicolumn{2}{c}{ Years } & \\
\cline { 2 - 3 } Phosphorus (kg ha & & \\
\cline { 2 - 3 } 0 & $\mathbf{2 0 1 1}$ & $\mathbf{2 0 1 2}$ & Mean \\
\hline 0 & 5.74 & 6.18 & $5.96 \mathrm{c}$ \\
80 & 6.55 & 7.39 & $6.97 \mathrm{~b}$ \\
120 & 7.14 & 8.41 & $7.77 \mathrm{a}$ \\
\hline LSD $_{0.05}$ & 7.15 & 8.69 & $7.92 \mathrm{a}$ \\
\hline Zinc $\left(\mathrm{kg} \mathrm{ha}^{-1}\right)$ & 0.46 & 0.59 & 0.36 \\
0 & & & \\
5 & 6.36 & 7.03 & $6.69 \mathrm{~b}$ \\
10 & 6.70 & 7.65 & $7.18 \mathrm{a}$ \\
15 & 6.80 & 7.88 & $7.34 \mathrm{a}$ \\
\hline LSD & 6.71 & 8.12 & $7.41 \mathrm{a}$ \\
\hline Genotypes & $\mathrm{ns}$ & 0.38 & 0.27 \\
B-385 (fine) & & & \\
F-Malakand (coarse) & 5.91 & 7.09 & $6.50 \mathrm{c}$ \\
Pukhraj (coarse) & 6.07 & 7.61 & $6.84 \mathrm{~b}$ \\
\hline LSD & 7.94 & 8.30 & $8.12 \mathrm{a}$ \\
\hline Years mean & 0.40 & 0.51 & 0.32 \\
\hline
\end{tabular}

Means of the same category followed by different letters are significantly different at $5 \%$ level of probability using LSD test. Significant interactions are $\mathrm{P} \times \mathrm{G}^{*}$ (Figure 1) and $\mathrm{P} \times \mathrm{Zn} \times \mathrm{G}^{* * *}$ (Figure 3). Where ns = non-significant data., while ${ }^{*}$ and ${ }^{* * *}$ stands for significant data at 5 and $0.1 \%$ level of probability, respectively. 


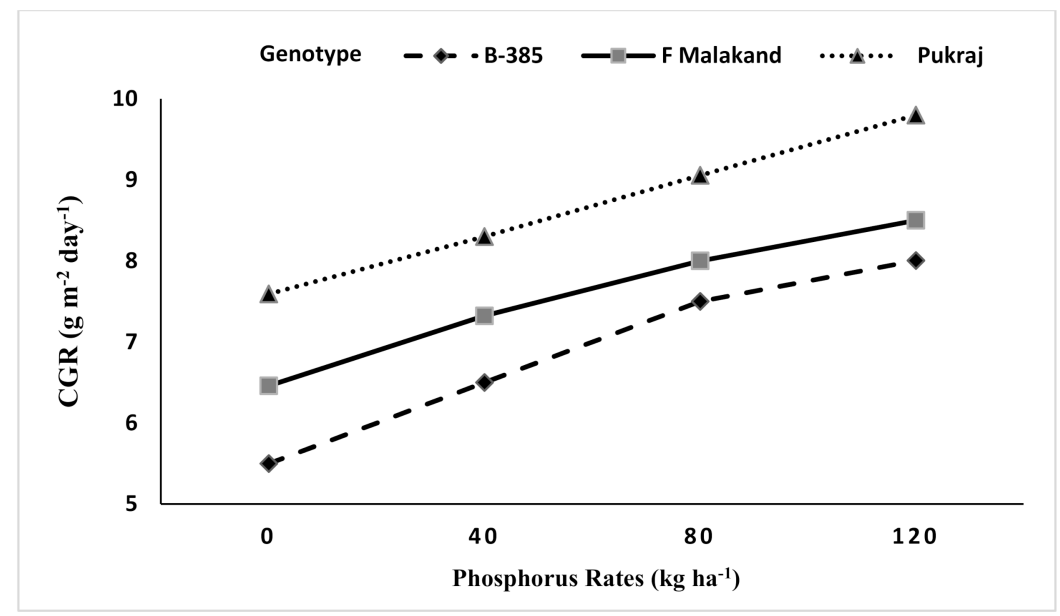

Figure 1. Crop growth rate $\left(\mathrm{g} \mathrm{m}^{-2} \mathrm{day}^{-1}\right)$ from transplanting to tillering of rice as affected by phosphorus into genotype $(\mathrm{P} \times \mathrm{G})$ interaction.

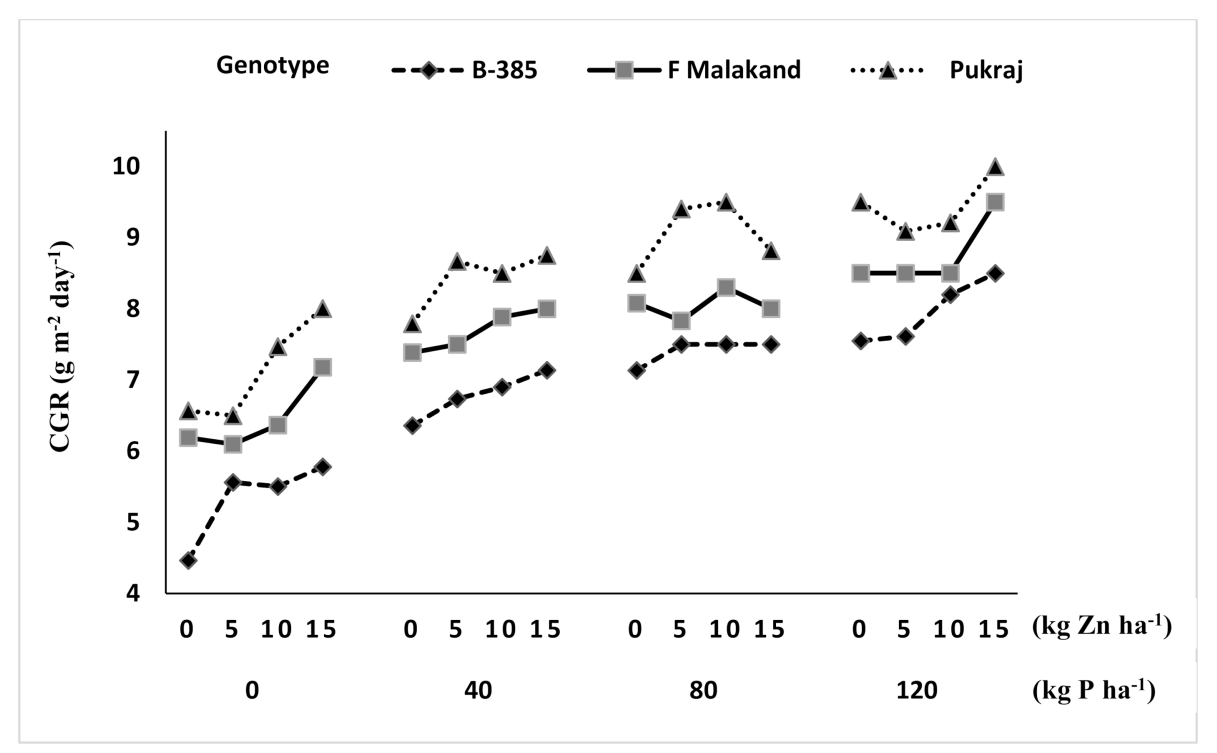

Figure 2. Crop growth rate $\left(\mathrm{g} \mathrm{m}^{-2} \mathrm{day}^{-1}\right)$ from transplanting to tillering of rice as affected by phosphorus into zinc into genotype $(\mathrm{P} \times \mathrm{Zn} \times \mathrm{G})$ interaction.

\subsection{Crop Growth Rate from Tillering to Heading}

The crop growth rate from tillering to heading was significantly affected $\mathrm{P}$ and $\mathrm{Zn}$ rates, genotypes and years (Table 1). The interactions $\mathrm{Y} \times \mathrm{G}, \mathrm{P} \times \mathrm{G}$ and $\mathrm{P} \times \mathrm{Zn} \times \mathrm{G}$ were also significant (Table 1). The highest CGR $\left(46.9 \mathrm{~g} \mathrm{~m}^{-2} \mathrm{day}^{-1}\right)$ was recorded for $120 \mathrm{~kg} \mathrm{P} \mathrm{ha}^{-1}$, while minimum CGR $\left(28.7 \mathrm{~g} \mathrm{~m}^{-2}\right.$ day $^{-1}$ ) was observed for P control plots (Table 3). In the case of $\mathrm{Zn}$ rates, maximum CGR $\left(41.3 \mathrm{~g} \mathrm{~m}^{-2} \mathrm{day}^{-1}\right)$ was recorded for $15 \mathrm{~kg} \mathrm{Zn} \mathrm{ha}^{-1}$, and the $\mathrm{Zn}$ control plots had the minimum CGR value of $37.6 \mathrm{~g} \mathrm{~m}^{-2}$ day $^{-1}$ (Table 3). Among the three rice genotypes, maximum CGR $\left(49.8 \mathrm{~g} \mathrm{~m}^{-2} \mathrm{day}^{-1}\right)$ was recorded for Pukhraj, followed by F-Malakand $\left(38.5 \mathrm{~g} \mathrm{~m}^{-2}\right.$ day $\left.^{-1}\right)$, and the minimum CGR (30.4 $\mathrm{g} \mathrm{m}^{-2}$ day $^{-1}$ ) was recorded for B-385 (Table 3).

In the case of $Y \times G$ interaction (Table 3), an increase in CGR for all three rice genotypes was noticed in $\mathrm{Y} 2$ over $\mathrm{Y} 1$. The CGR of coarse genotypes was more than the fine genotype (Table 3). The Y2 had higher CGR $\left(44.6 \mathrm{~g} \mathrm{~m}^{-2}\right.$ day $\left.^{-1}\right)$ as compared with Y1 $\left(34.5 \mathrm{~g} \mathrm{~m}^{-2}\right.$ day $\left.^{-1}\right)$. The increase in P level had increased the CGR in all three cultivars but the response of the Pukhraj was more to the higher $P$ level than the other two genotypes (Figure 3). The three-way interaction among $\mathrm{P} \times \mathrm{Zn} \times \mathrm{G}$ (Figure 4) indicated that Pukhraj (the hybrid rice) had a higher CGR at each P level along with the highest rate of 
$15 \mathrm{~kg} \mathrm{Zn} \mathrm{ha}{ }^{-1}$. The two local genotypes of rice (F-Malakand and B-385) had higher CGR at each P level when applied in combination with $10 \mathrm{~kg} \mathrm{Zn} \mathrm{ha}^{-1}$ (Figure 4).

Table 3. Crop growth rate $\left(\mathrm{g} \mathrm{m}^{-2}\right.$ day $\left.^{-1}\right)$ from tillering to heading of rice genotypes as affected by phosphorus and zinc application.

\begin{tabular}{lccc}
\hline & \multicolumn{2}{c}{ Years } & \\
\cline { 2 - 3 } Phosphorus (kg ha & \\
\cline { 2 - 3 } & $\mathbf{1})$ & $\mathbf{2 0 1 1}$ & Mean \\
\hline 0 & 25.9 & 31.4 & $28.7 \mathrm{~d}$ \\
40 & 33.6 & 43.7 & $38.7 \mathrm{c}$ \\
80 & 38.4 & 49.7 & $44.0 \mathrm{~b}$ \\
120 & 40.0 & 53.7 & $46.9 \mathrm{a}$ \\
\hline LSD $_{0.05}$ & 1.45 & 1.84 & 0.99 \\
\hline Zinc (kg ha & \\
0 & & & \\
5 & 32.7 & 42.6 & $37.6 \mathrm{~d}$ \\
10 & 33.7 & 43.8 & $38.8 \mathrm{c}$ \\
15 & 35.5 & 45.5 & $40.5 \mathrm{~b}$ \\
\hline LSD & 36.0 & 46.6 & $41.3 \mathrm{a}$ \\
\hline Genotypes & 1.36 & 1.27 & 0.79 \\
B-385 (fine) & & & \\
F-Malakand (coarse) & 28.2 & 32.5 & $30.4 \mathrm{c}$ \\
Pukhraj (coarse) & 34.3 & 42.7 & $38.5 \mathrm{~b}$ \\
\hline LSD 0.05 & 40.9 & 58.7 & $49.8 \mathrm{a}$ \\
\hline Years mean & 1.26 & 1.60 & 1.14 \\
\hline
\end{tabular}

Means of the same category followed by different letters are significantly different at $5 \%$ level of probability using least significant difference (LSD) test. Significant interactions are $P \times G *$ (Figure 3 ) and $P \times Z n \times G * *$ (Figure 4). Where $n s=$ non-significant data, while ${ }^{*}$ and ${ }^{* * *}$ stands for significant data at 5 and $0.1 \%$ level of probability, respectively.

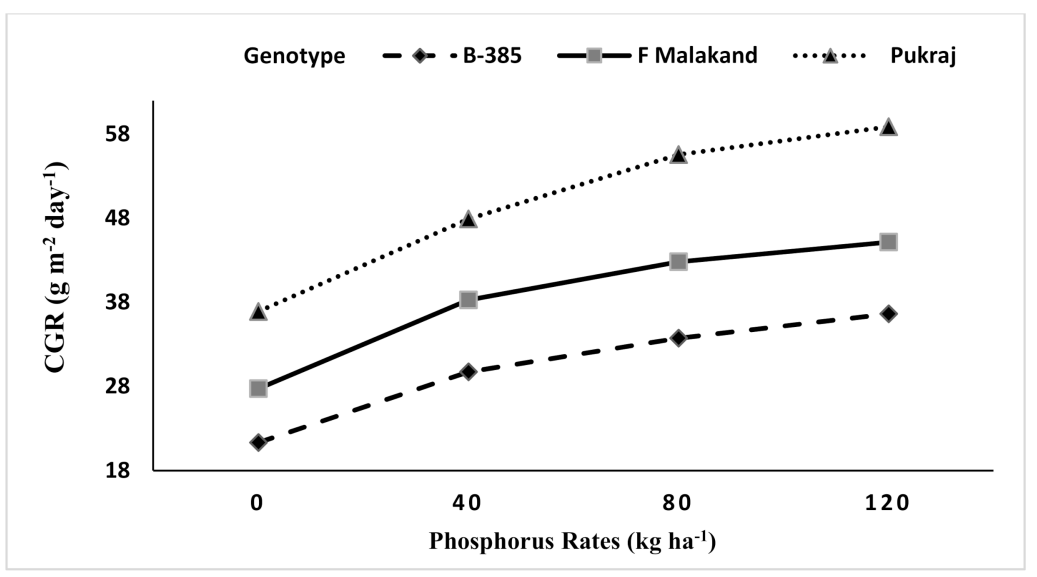

Figure 3. Crop growth rate $\left(\mathrm{g} \mathrm{m}^{-2}\right.$ day $\left.^{-1}\right)$ from tillering to heading of rice as affected by phosphorus into genotype $(\mathrm{P} \times \mathrm{G})$ interaction. 


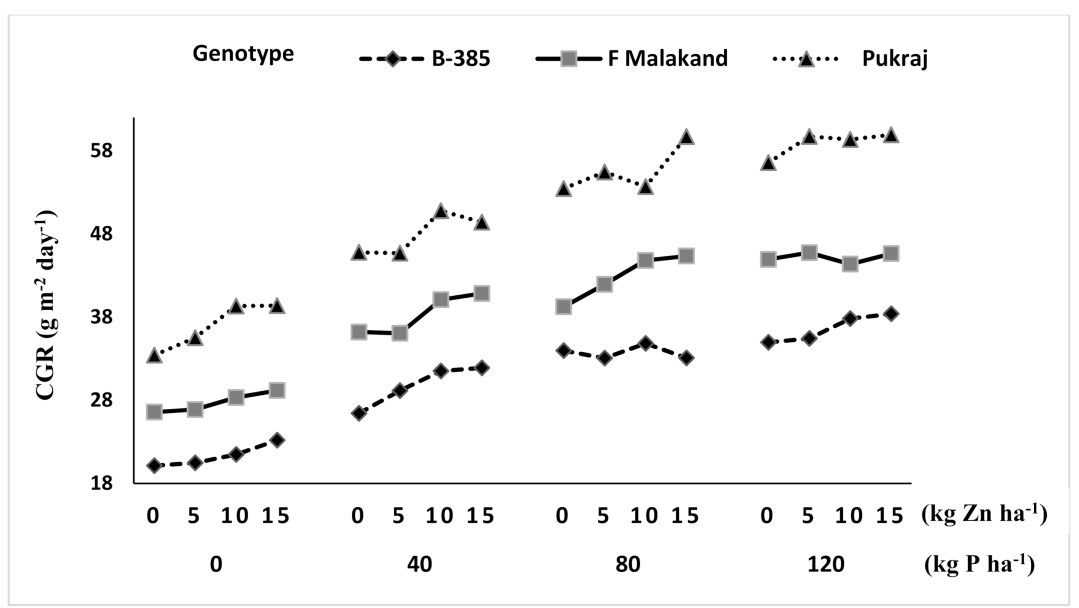

Figure 4. Crop growth rate $\left(\mathrm{g} \mathrm{m}^{-2}\right.$ day $\left.^{-1}\right)$ from tillering to heading of rice as affected by phosphorus into zinc into genotypes $(\mathrm{P} \times \mathrm{Zn} \times \mathrm{G})$ interaction.

\subsection{Crop Growth Rate from Heading to Physiological Maturity}

The $\mathrm{P}$ and $\mathrm{Zn}$ rates and genotypes had significantly affected CGRs from heading to physiological maturity (Table 1). Years and all interactions except $Y \times G$ had no significant effect on the CGR (Table 1). The highest CGR (14.71 $\left.\mathrm{g} \mathrm{m}^{-2} \mathrm{day}^{-1}\right)$ was recorded with the application of $120 \mathrm{~kg} \mathrm{P} \mathrm{ha}^{-1}$ which was statistically identical with 40 and $80 \mathrm{~kg} \mathrm{P} \mathrm{ha}^{-1}$, and the minimum CGR $\left(8.60 \mathrm{~g} \mathrm{~m}^{-2} \mathrm{day}^{-1}\right)$ was observed for P control plots (Table 4). In the case of Zn rates, the maximum CGR $\left(14.73 \mathrm{~g} \mathrm{~m}^{-2} \mathrm{day}^{-1}\right)$ was recorded with $15 \mathrm{~kg} \mathrm{Zn} \mathrm{ha}^{-1}$ being at par with $10 \mathrm{~kg} \mathrm{Zn} \mathrm{ha}^{-1}\left(13.25 \mathrm{~g} \mathrm{~m}^{-2}\right.$ day $\left.^{-1}\right)$, and the minimum CGR (11.09 $\mathrm{g} \mathrm{m}^{-2} \mathrm{day}^{-1}$ ) was recorded for zinc control plots (Table 4). Among the three rice genotypes, maximum CGR (13.57 $\mathrm{g} \mathrm{m}^{-2}$ day $\left.^{-1}\right)$ was recorded for Pukhraj, followed by F-Malakand $\left(11.85 \mathrm{~g} \mathrm{~m}^{-2}\right.$ day $\left.^{-1}\right)$, while minimum CGR $\left(8.25 \mathrm{~g} \mathrm{~m}^{-2}\right.$ day $\left.^{-1}\right)$ was recorded for B-385 (Table 4).

Table 4. Crop growth rate $\left(\mathrm{g} \mathrm{m}^{-2} \mathrm{day}^{-1}\right)$ from heading to physiological maturity of rice genotypes as affected by phosphorus and zinc application.

\begin{tabular}{lccc}
\hline & \multicolumn{2}{c}{ Years } & \\
\cline { 2 - 3 } Phosphorus (kg ha $\left.{ }^{-1}\right)$ & $\mathbf{2 0 1 1}$ & $\mathbf{2 0 1 2}$ & Mean \\
\hline 0 & 10.72 & 6.47 & $8.60 \mathrm{~b}$ \\
40 & 14.11 & 13.88 & $13.99 \mathrm{a}$ \\
80 & 14.92 & 13.58 & $14.25 \mathrm{a}$ \\
120 & 15.49 & 13.93 & $14.71 \mathrm{a}$ \\
\hline LSD $_{0.05}$ & $\mathrm{~ns}$ & 4.47 & 2.28 \\
\hline Zinc $\left(\mathrm{kg} \mathrm{ha}^{-1}\right)$ & & & \\
0 & 12.53 & 9.65 & $11.09 \mathrm{c}$ \\
5 & 12.99 & 11.97 & $12.48 \mathrm{bc}$ \\
10 & 13.94 & 12.57 & $13.25 \mathrm{ab}$ \\
15 & 15.78 & 13.68 & $14.73 \mathrm{a}$ \\
\hline LSD $_{0.05}$ & $\mathrm{~ns}$ & 3.38 & 2.16 \\
\hline Genotypes & & & \\
B-385 (fine) & 6.99 & 9.50 & $8.25 \mathrm{c}$ \\
F-Malakand (coarse) & 10.13 & 13.57 & $11.85 \mathrm{~b}$ \\
Pukhraj (coarse) & 14.31 & 12.83 & $13.57 \mathrm{a}$ \\
\hline LSD & 2.05 & 3.35 & 1.98 \\
\hline Years mean & 13.81 & 11.96 & \\
\hline
\end{tabular}

Means of the same category followed by different letters are significantly different at $5 \%$ level of probability using LSD test. Where ns = non-significant data. 
In the interaction between $Y \times G$ (Table 4) indicated that the CGR of F-Malakand and B-385 was higher in $\mathrm{Y} 2$ than $\mathrm{Y} 1$, in the case of hybrid rice (Pukhraj) the CGR was higher in $\mathrm{Y} 1$ than in $\mathrm{Y} 2$.

\subsection{Total Rice Biomass/Biological Yield at Harvest}

Total Biomass yield (BY) at harvest was significantly affected by $\mathrm{P}$ and $\mathrm{Zn}$ rates, and genotypes (Table 1). Years and all interactions except $P \times G$ and $P \times Z n \times G$ were found non-significant for BY (Table 1). The highest BY $\left(19,114 \mathrm{~kg} \mathrm{ha}^{-1}\right)$ was obtained with $120 \mathrm{~kg} \mathrm{P} \mathrm{ha}^{-1}$ being at par with $80 \mathrm{~kg} \mathrm{P} \mathrm{ha}^{-1}\left(18,938 \mathrm{~kg} \mathrm{ha}^{-1}\right)$, and minimum BY $\left(16,726 \mathrm{~kg} \mathrm{ha}^{-1}\right)$ was recorded for P control plots (Table 5). In the case of $\mathrm{Zn}$ rates, maximum BY (18,835 $\left.\mathrm{kg} \mathrm{ha}^{-1}\right)$ was obtained with $10 \mathrm{~kg} \mathrm{Zn} \mathrm{ha}^{-1}$ being at par with $15 \mathrm{~kg} \mathrm{Zn} \mathrm{ha}^{-1}\left(18,523 \mathrm{~kg} \mathrm{ha}^{-1}\right)$, and the minimum BY $\left(17,566 \mathrm{~kg} \mathrm{ha}^{-1}\right)$ was recorded for zinc control plots (Table 5). The interaction of $\mathrm{Y} \times \mathrm{Zn}$ (Table 5) indicated that the BY was higher at all $\mathrm{Zn}$ rates in Y2 than Y1. Among the three rice genotypes, maximum BY $\left(19,785 \mathrm{~kg} \mathrm{ha}^{-1}\right)$ was recorded for Pukhraj, followed by F-Malakand $\left(19,125 \mathrm{~kg} \mathrm{ha}^{-1}\right)$, and minimum BY $\left(15,762 \mathrm{~kg} \mathrm{ha}^{-1}\right)$ was recorded for B-385 (Table 5).

The interaction of $P \times G$ revealed that an increase in $P$ rates up to $80 \mathrm{~kg} \mathrm{ha}^{-1}$ increased $B Y$ of Pukhraj and B-385 (Figure 5). The BY of F-Malakand was decreased with an increasing P level up to $80 \mathrm{~kg} \mathrm{ha}^{-1}$, but a further increase in P level increased BY of F-Malakand (Figure 5). The three-way interaction among $\mathrm{P} \times \mathrm{Zn} \times \mathrm{G}$ indicated that Pukhraj had the highest BY at $80 \mathrm{~kg} \mathrm{P}+10 \mathrm{~kg} \mathrm{Zn} \mathrm{ha}^{-1}$ (Figure 6), while in the case of two local cultivars (F-Malakand and B-385), a higher BY was obtained at $120 \mathrm{~kg} \mathrm{P}+15 \mathrm{~kg} \mathrm{Zn} \mathrm{ha-1}$ (Figure 6).

Table 5. Biomass/biological yield $\left(\mathrm{kg} \mathrm{ha}^{-1}\right)$ of rice genotypes as affected by phosphorus and zinc application.

\begin{tabular}{|c|c|c|c|}
\hline \multirow[b]{2}{*}{ Phosphorus (kg ha ${ }^{-1}$ ) } & \multicolumn{2}{|c|}{ Years } & \multirow[b]{2}{*}{ Mean } \\
\hline & 2011 & 2012 & \\
\hline 0 & 16,555 & 16,898 & $16,726 c$ \\
\hline 40 & 17,997 & 18,239 & $18,118 \mathrm{~b}$ \\
\hline 80 & 18,303 & 19,573 & $18,938 \mathrm{a}$ \\
\hline 120 & 18,268 & 19,960 & $19,114 \mathrm{a}$ \\
\hline $\mathrm{LSD}_{0.05}$ & 1030 & 922 & 672 \\
\hline \multicolumn{4}{|l|}{ Zinc $\left(\mathrm{kg} \mathrm{ha}^{-1}\right)$} \\
\hline 0 & 17,114 & 18,018 & $17,566 \mathrm{~b}$ \\
\hline 5 & 17,453 & 18,493 & $17,973 \mathrm{~b}$ \\
\hline 10 & 18,383 & 19,286 & $18,835 \mathrm{a}$ \\
\hline 15 & 18,174 & 18,872 & $18,523 \mathrm{a}$ \\
\hline $\mathrm{LSD}_{0.05}$ & 678 & 700 & 483 \\
\hline \multicolumn{4}{|l|}{ Genotypes } \\
\hline B-385 (fine) & 15,148 & 16,376 & $15,762 \mathrm{c}$ \\
\hline F-Malakand (coarse) & 18,884 & 19,366 & $19,125 \mathrm{~b}$ \\
\hline Pukhraj (coarse) & 19,310 & 20,259 & $19,785 a$ \\
\hline $\mathrm{LSD}_{0.05}$ & 892 & 799 & 582 \\
\hline Years mean & 17,781 & 18,667 & \\
\hline
\end{tabular}

Means of the same category followed by different letters are significantly different at $5 \%$ level of probability using LSD test. Significant interactions for BY are $\mathrm{P} \times \mathrm{G}^{*}$ (Figure 5) and $\mathrm{P} \times \mathrm{Zn} \times \mathrm{G}^{* * *}$ (Figure 6). Where ns $=$ non-significant data, while ${ }^{*}$ and ${ }^{* * *}$ stands for significant data at 5 and $0.1 \%$ level of probability, respectively. 


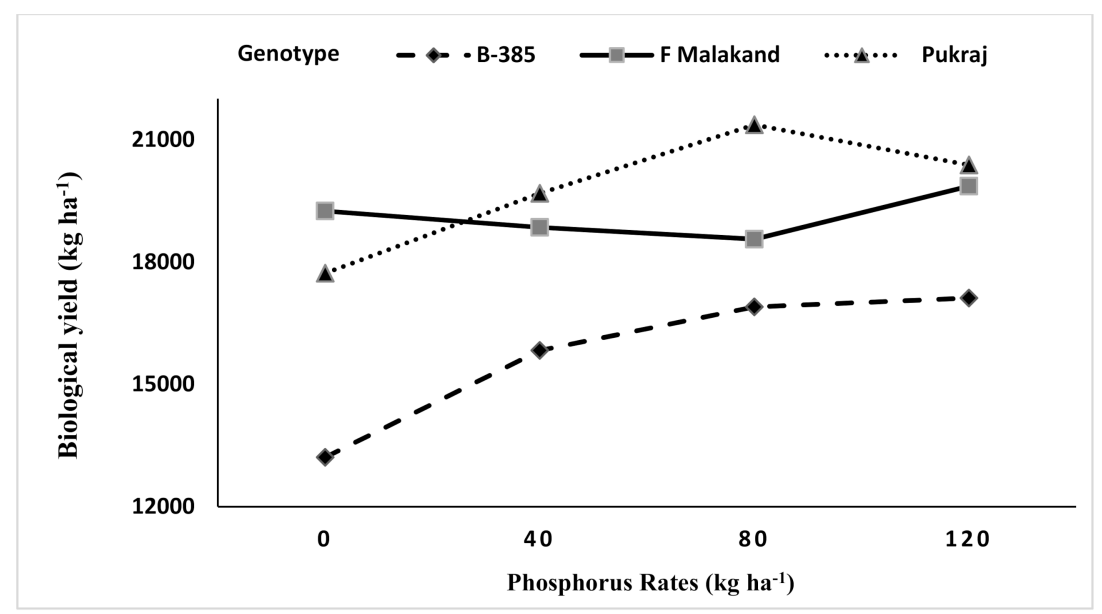

Figure 5. Biological yield $\left(\mathrm{kg} \mathrm{ha}^{-1}\right)$ of rice as affected by phosphorus into genotypes $(\mathrm{P} \times \mathrm{G})$ interaction.

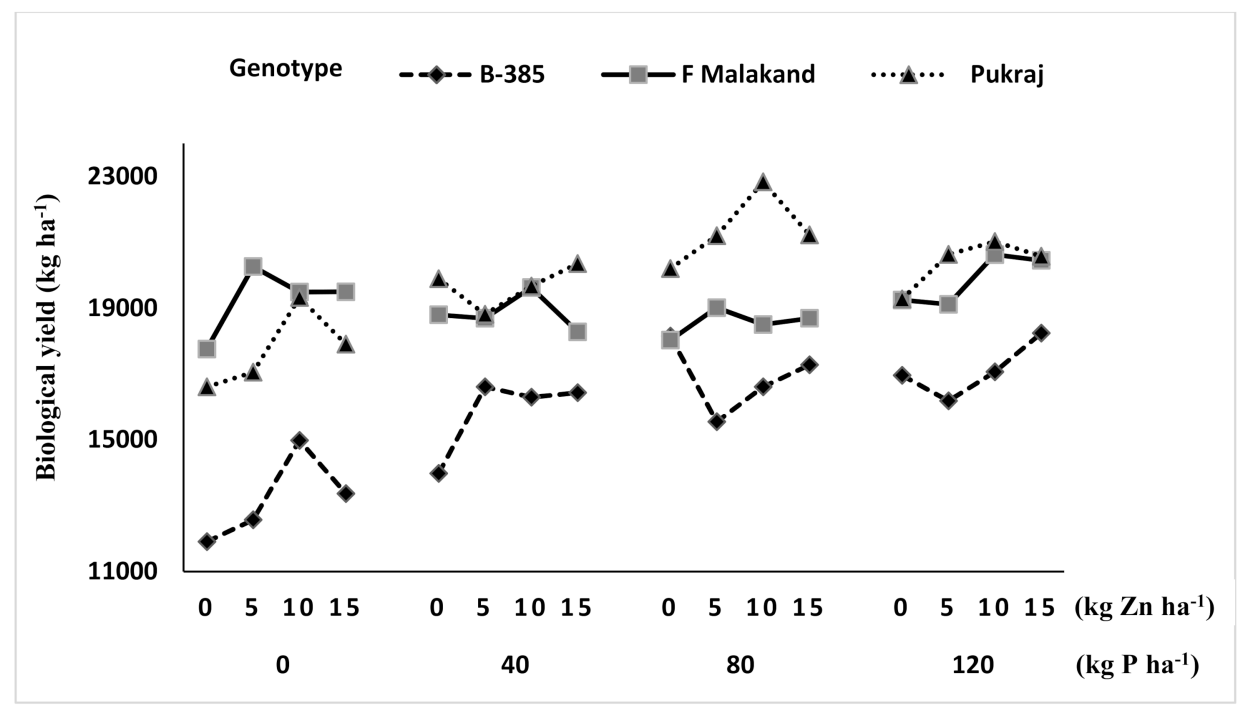

Figure 6. Biological yield $\left(\mathrm{kg} \mathrm{ha}^{-1}\right)$ of rice as affected by phosphorus into zinc into genotypes $(\mathrm{P} \times \mathrm{Zn} \times \mathrm{G})$ interaction.

\section{Discussion}

\subsection{Crop Growth Rate at Different Growth Stages}

The CGR depends on the amount of radiation intercepted by the crop and on the efficiency of conversion of intercepted radiation into dry matter. In this study, the CGR at different growth stages increased with the application of higher P rates $\left(80\right.$ and $\left.120 \mathrm{~kg} \mathrm{P} \mathrm{ha}^{-1}\right)$ and higher $\mathrm{Zn}$ rates $(10$ and $\left.15 \mathrm{~kg} \mathrm{Zn} \mathrm{ha}^{-1}\right)$ and the increase was higher when both nutrients were applied in combination $(\mathrm{P} \times \mathrm{Zn})$ than sole P or sole $\mathrm{Zn}$ application (Table 2, Table 3 andTable 4). The CGR decreased significantly $(p \leq 0.05)$ at all three growth stages with the application of no (control) or lower $\mathrm{P}\left(0\right.$ and $\left.40 \mathrm{~kg} \mathrm{P} \mathrm{ha}^{-1}\right)$ and $\mathrm{Zn}$ rates $\left(0\right.$ and $\left.5 \mathrm{~kg} \mathrm{Zn} \mathrm{ha}{ }^{-1}\right)$. According to [27], the application of both $\mathrm{P}$ and $\mathrm{Zn}$ significantly increased total dry matter accumulation in rice. They reported the highest increase when both $P$ and Zn were combined at their respective highest rates (100 and $10 \mathrm{ppm}$, respectively), the mean increase of shoots, roots and grains was 35,39 and $25 \%$ higher over control (P0Zn0), respectively. The increase in CGR resulting from the combined application of $\mathrm{P}$ and $\mathrm{Zn}$ probably may be due to their beneficial effect on leaf area index [6], DMP [24], plants P and Zn contents [5] and higher yield and yield components [2]. The increase in dry matter accumulation with the application of $\mathrm{P}$ and $\mathrm{Zn}$ was also reported by other researchers [28-30]. According to [31], DM accumulation increased with an increased Zn level. 
However, they reported maximum dry matter production with $40 \mathrm{~kg} \mathrm{Zn} \mathrm{ha}{ }^{-1}$. This contradiction might be due to differences in soil and environmental conditions as well as genotypes used. In our study, we confirmed that the increase in the CGR in rice crop with the application of higher P and Zn rates was attributed to their corresponding increase in the leaf area index [6]. This is because the increase in leaf area index probably increased the light interaction [32] that improved the CGR in this study.

The two coarse genotypes performed better than the fine genotype in terms of higher CGR (Table 2, Table 3 and Table 4) at different growth stages. According to [33], wide variability in photosynthetic rate (CGR) exits in rice genotypes. Earlier, [34] found that a high photosynthetic rate in crops is associated with higher productivity. The increase in the CGR in the course rice genotypes (Fakhre-e-Malakand and Pukhraj) over fine genotype (Basmati-385) was attributed to the higher leaf area index [6], increase in DMP into various plant parts [24] grain yield [2]. The increase in leaf area index and the corresponding increase in light interception [32] probably resulted in higher CGR in rice. Our results are supported by [28] who reported differences in DM accumulation while growing different rice genotypes. This was expected since coarse genotypes take more nutrients ( $\mathrm{P}$ and $\mathrm{Zn}$ ) from soil [9], accumulate more $\mathrm{Zn}$ in plants [5] and partition more dry matter into various plant parts [24], thus resulting in a higher CGR. According to [35], DM production in six rice genotypes was significantly affected by P rates. An increase in DM accumulation or higher CGR is important because it is significantly associated with grain yield [2] and harvest index [8]. Hybrid rice genotypes had higher efficiency in DMP and, consequently, had higher grain yields than inbred lines $[24,36]$.

\subsection{Biomass Yield}

Yield is defined as the amount of specific substance produced (e.g., grain, straw, total dry matter) per unit area. The results of our current study revealed that the BY in rice genotypes increased with the application of higher P (80 and $\left.120 \mathrm{~kg} \mathrm{P} \mathrm{ha}^{-1}\right)$ and higher $\mathrm{Zn}$ rates $\left(10\right.$ and $\left.15 \mathrm{~kg} \mathrm{Zn} \mathrm{ha}^{-1}\right)$. The increase in $\mathrm{BY}$ was more when both nutrients were applied in combination $(\mathrm{P}+\mathrm{Zn})$ than sole $(\mathrm{P}$ or $\mathrm{Zn})$ applications (Table 5). The BY decreased tremendously with the application of lower $\mathrm{P}(0$ and $\left.40 \mathrm{~kg} \mathrm{P} \mathrm{ha}^{-1}\right)$ and lower $\mathrm{Zn}$ rates $\left(0\right.$ and $\left.5 \mathrm{~kg} \mathrm{Zn} \mathrm{ha}^{-1}\right)$. In this study, the CGR showed a positive relationship with total BY. Ref. [37] reported an increase of $80 \%$ in BY and $180 \%$ in grain yield of rice with the application of a higher P rate of $131 \mathrm{~kg} \mathrm{P} \mathrm{ha}^{-1}$ over P-control plots. Ref. [38] reported that P application increased grain yield of different rice genotypes and the differences in yield were attributed with an increase in panicle number and BY. Similarly, [39] reported that BY and grain yield of rice increased with the application of $\mathrm{Zn}$ in the soil. They reported maximum BY with the application of $5 \mathrm{mg} \mathrm{Zn} \mathrm{kg}{ }^{-1}$ of soil, which was about $33 \%$ greater than $\mathrm{Zn}$-control plots, and maximum grain yield was achieved with the application of $20 \mathrm{mg} \mathrm{Zn} \mathrm{kg}^{-1}$ of soil that was about $97 \%$ more than Zn-control plots. Likewise, [31] reported a significant effect of $\mathrm{Zn}$ fertilizer on grain, biomass and straw yields as well as the harvest of rice. According to [40], straw and paddy yield showed an increasing trend up to $9 \mathrm{~kg} \mathrm{Zn} \mathrm{ha}{ }^{-1}$. They reported the highest average paddy yield and yield components were recorded at $120 \mathrm{~kg} \mathrm{~N}+90 \mathrm{~kg} \mathrm{P}_{2} \mathrm{O}_{5}$ along with $9 \mathrm{~kg} \mathrm{Zn} \mathrm{ha}^{-1}$.

Our results confirmed that both $\mathrm{P}$ and $\mathrm{Zn}$ application at higher rates in combination improved the leaf area index of rice [6], increased DMP into various plant parts [6], increased yield components and grain yield [2] hence the BY in rice was increased. Ref. [41] reported that $\mathrm{Zn}$ and P either alone or in combination showed a significantly positive effect on the grain and straw yield of rice. Similarly, [42] found that grain yield and BY in rice reached a maximum with the combined application of $33 \mathrm{~kg}$ $\mathrm{P}+12 \mathrm{~kg} \mathrm{Zn} \mathrm{ha}{ }^{-1}$. Grain yield in cereals is related to BY and harvest index because the BY is a function of crop growth duration and CGR at successive growth stages [43]. In the present study, the total BY was more at heading (heading > physiological > tillering). Ref. [44] reported a reduction in shoot dry weight of upland rice from flowering to physiological maturity. The higher BY indicates more translocation of assimilates from the leaf, leaf sheaths and stems to the panicles during the grain filling period, resulting in higher grain yield [36]. The BY in this study decreased significantly $(p \leq 0.05)$ with the application of no or lower $\mathrm{P}\left(0\right.$ and $\left.40 \mathrm{~kg} \mathrm{P} \mathrm{ha}^{-1}\right)$ and $\mathrm{Zn}$ rates $\left(0\right.$ and $\left.5 \mathrm{~kg} \mathrm{Zn} \mathrm{ha}^{-1}\right)$. These results 
are in agreement with the results of [45] who reported that macro- as well as micronutrient deficiencies are the most important nutritional disorders that limit crop yields.

The coarse rice genotypes (Pukhraj and F-Malakand) in this study produced more BY than the fine genotype (B-385) as shown in Table 5. The increase in BY of coarse genotypes was attributed to the higher leaf area index [6], higher DMP into different plant parts [24] and the higher number of panicles hill $^{-1}$, more filled grains panicle ${ }^{-1}$ and heavy grains [2] than the fine genotype. Ref. [46] found very interesting results while comparing different maize genotypes. They reported that the hybrid maize (Pioneer-3025) with higher leaf area index (LAI) also produced higher total biomass than the two local varieties (Azam and Jalal). Likewise, [36] reported that the two hybrids (SL8 and Bigante) had higher grain and BY than the check genotype, IR72. Ref. [31] reported significant differences in yield and yield parameters of different rice genotypes. Significant differences in yields have been reported among crop species and genotypes of the same species in the absorption and utilization of nutrients including P [44,47]. Further increase in grain yield in cereals such as rice through breeding can only be accomplished with an increase in total BY. According to [48], grain yield improvement of lowland rice cultivars released by the International Rice Research Institute (IRRI) in the Philippines after 1980 was due to increases in biomass production. Reference $[49,50]$ made comparisons among the improved semi-dwarf cultivars, and higher grain yield was achieved by increasing biomass production.

\section{Conclusions}

Phosphorus and zinc management is one of the most important strategies for improving growth and total biomass. Zinc into phosphorus interaction imbalance in the rice plant results in excessive phosphorus accumulation causing zinc-imposed deficiency, resulting in lower crop growth rate (CGR) and total biomass/biological yield (BY). The BY $\left(19,114 \mathrm{~kg} \mathrm{ha}^{-1}\right)$ ranked maximum with the highest rate of $120 \mathrm{~kg} \mathrm{P} \mathrm{ha}^{-1}$ and decreased to a minimum $\left(16,726 \mathrm{~kg} \mathrm{ha}^{-1}\right)$ in P control plots. Maximum BY $\left(18,835 \mathrm{~kg} \mathrm{ha}^{-1}\right)$ was obtained with $10 \mathrm{~kg} \mathrm{Zn} \mathrm{ha}^{-1}$ and the minimum BY $\left(17,566 \mathrm{~kg} \mathrm{ha}^{-1}\right)$ was recorded for $\mathrm{Zn}$ control plots. The results of our study confirmed that the integrated application of phosphorus and zinc at higher rates was more beneficial in terms of higher CGR and BY in all three genotypes under study. The sole application of $\mathrm{P}$ and $\mathrm{Zn}$ or no application ( $\mathrm{P}$ and $\mathrm{Zn}$ not applied) reduced both CGR and BY. The higher CGR of rice hybrid (Pukhraj) was attributed to its higher leaf area index because of its long and wider leaves, and higher dry matter accumulation and partitioning. The CGR showed a positive relationship with total BY. The increase in BY had a positive impact on grain yield and grower's income.

Author Contributions: A. designed and supervised the research project, drafted and revised the manuscript, and I. carried out the lab and field studies. J.A., M.S.E., M.S.A., A.M., M.A., and S.K. checked and reviewed the manuscript. All authors have read and agreed to the published version of the manuscript.

Funding: This research received no external funding.

Acknowledgments: We are highly thankful to Paigham Shah, The University of Agriculture Peshawar (retired) for the statistical analysis of the data. We are also thankful to the Department of Agronomy, The University of Agriculture Peshawar, Pakistan for helping and encouraging us to conduct this research work at farmer field in Malakand (Batkhela). We are also thankful to the two foreign distinguished professors: (1) Bob A. Stewart (Director and Distinguished Professor Dryland Agriculture Institute, West Texas A\&M University, WTAMU, Texas-USA) and (2) Davey Jones (School of the Environment and Natural Resources, Bangor University, Bangor, $\mathrm{UK})$ for checking and recommending this research work for the award of PhD degree to Inamullah. The authors extend their appreciation to the Researchers Supporting Project number (RSP-2020/173) King Saud University, Riyadh, Saudi Arabia.

Conflicts of Interest: The authors declare no conflict of interest. 


\section{References}

1. Confalonieri, R.; Bocchi, S. Evaluation of Crop Syst for simulating the yield of flooded rice in northern Italy. Eur. J. Agron. 2005, 23, 315-326. [CrossRef]

2. Amanullah; Inamullah; Alkahtani, J.; Elshikh, M.S.; Alwahibi, M.S.; Muhammad, A.; Imran; Khalid, S. Phosphorus and Zinc Fertilization improve productivity and profitability of rice cultivars under rice-wheat system. Agronomy 2020, 10, 1085. [CrossRef]

3. Swaminathan, M. Can science and technology feed the world in 2025? Field Crop. Res. 2007, 104, 3-9. [CrossRef]

4. Rosegrant, M.W.; Agcaoili-Sombilla, M.; Perez, N.D. Global Food Projections to 2020: Implications for Investment; Food, Agriculture, and Environment Discussion. Paper No. 5; IFPRI: Washington, DC, USA, 1995.

5. Amanullah; Inamullah; Alwahibi, M.S.; Elshikh, M.S.; Alkahtani, J.; Muhammad, A.; Khalid, S.; Imran; Ahmad, M.; Khan, N.; et al. Phosphorus and zinc fertilization improve zinc biofortification in grains and straw of coarse vs. fine rice genotypes. Agronomy 2020, 10, 1155. [CrossRef]

6. Amanullah; Inamullah; Shah, Z.; Khalil, S.K. Phosphorus and zinc interaction influence leaf area index in fine versus coarse rice (Oryza sativa L.) genotypes in Northwest Pakistan. J. Plant Stress Physiol. 2016, 2, 1-8.

7. Jan, A.; Wasim, M.; Amanullah. Interactive effects of zinc and nitrogen application on wheat growth and grain yield. J. Plant Nutr. 2013, 36, 1506-1520. [CrossRef]

8. Amanullah; Inamullah. Preceding rice genotypes, residual phosphorus and zinc influence harvest index and biomass yield of subsequent wheat crop under rice-wheat system. Pak. J. Botany 2015, 47, 265-273.

9. Amanullah; Inamullah. Residual phosphorus and zinc influence wheat productivity under rice-wheat cropping system. SpringerPlus 2016, 5, 255. [CrossRef] [PubMed]

10. Marschner, H. Mineral Nutrition of Higher Plants, 2nd ed.; Academic Press: San Diego, CA, USA, 2002.

11. Rose, T.J.; Impa, S.M.; Rose, M.T.; Pariasca-Tanaka, J.; Mori, A.; Heuer, S.; Johnson-Beebout, S.E.; Wissuwa, M. Enhancing phosphorus and zinc acquisition efficiency in rice: A critical review of root traits and their potential utility in rice breeding. Ann. Bot. 2012, 112, 331-345. [CrossRef] [PubMed]

12. Cakmak, I. Possible roles of zinc in protecting plant cells from damage by reactive oxygen species. New Phytol. 2000, 146, 185-205. [CrossRef]

13. Mirvat, E.G.; Mohamed, M.H.; Tawfik, M.M. Effect of phosphorus fertilizer and foliar spraying with zinc on growth, yield and quality of groundnut under recLAPHmed sandy soils. J. Appl. Sci. Res. 2006, 2, 491-496.

14. Alloway, B.J. Soil factors associated with zinc deficiency in crops and humans. Environ. Geochem. Health 2009, 31, 537-548. [CrossRef] [PubMed]

15. Khorgamy, A.; Farnia, A. Effect of phosphorus and zinc fertilisation on yield and yield components of chickpea cultivars. Afr. Crop Sci. Conf. Proc. 2009, 9, 205-208.

16. Salimpour, S.; Khavazi, K.; Nadian, H.; Besharati, H.; Miransari, H. Enhancing phosphorus availability to canola (Brassica napus L.) using P solubilizing and sulfur oxidizing bacteria. Aust. J. Crop Sci. 2010, 4, 330-334.

17. Quijano-Guerta, C.; Kirk, G.J.D.; Portugal, A.; Bartolome, V.; McLaren, G. Tolerance of rice germplasm to zinc deficiency. Field Crop. Res. 2002, 76, 123-130. [CrossRef]

18. Singh, B.; Natesan, S.K.A.; Singh, B.K.; Usha, K. Improving zinc efficiency of cereals under zinc deficiency. Curr. Sci. 2003, 88, 36-44.

19. Tahir, M.; Kausar, M.A.; Ahmad, R.; Bhatti, S.A. Micronutrient status of Faisalabad and Sheikhupura soils. Pak. J. Agric. Res. 1991, 12, 134-140.

20. Qadar, A. Selecting rice genotypes tolerant to zinc deficiency and sodicity stresses. I. Differences in zinc, iron, manganese, copper, phosphorus concentrations, and phosphorus/zinc ratio in their leaves. J. Plant Nutr. 2002, 25, 457-473. [CrossRef]

21. Weng, J.H.; Chen, C.Y. Photosynthetic Characteristics, Dry Matter Production and Grain Yield of the First and the Second Rice Crops in Taiwan; TARI Special Publication, No. 16; Taiwan Agricultural Research Institute: Wufeng, Taichung, Taiwan, 1984; pp. 153-164.

22. Wu, G.; Wilson, L.T.; McClung, A.M. Contribution of Rice Tillers to Dry Matter Accumulation and Yield. Agron. J. 1907, 90, 317-323. [CrossRef]

23. Ying, J.; Peng, S.; He, Q.; Yang, H.; Yang, C.; Visperas, R.M.; Cassman, K.G. Comparison of high-yield rice in tropical and subtropical environments I. Determinants of grain and dry matter yields. Field Crop. Res. 1998, 57, 71-84. [CrossRef] 
24. Amanullah; Inamullah. DMP and harvest index differ in rice genotypes with variable rates of phosphorus and zinc nutrition. Rice Sci. 2016, 23, 78-87. [CrossRef]

25. Amanullah; Stewart, B.A. DMP, growth analysis and water use efficiency response of oats (Avena sativa L.) to excessive nitrogen and phosphorus application. J. Agric. Sci. Technol. 2013, 15, 479-489.

26. Steel, R.G.D.; Torrie, J.H.; Dickey, D. Principles and Procedures of Statistics; McGraw-Hill: New York, NY, USA, 1996.

27. Haldar, M.; Mandal, L.N. Effect of phosphorus and zinc on the growth and phosphorus, zinc, copper, iron and manganese nutrition of rice. Plant Soil 1981, 59, 415-425. [CrossRef]

28. Alam, M.M.; Ali, M.H.; Hasanuzzaman, M.; Nahar, K.; Islam, M.R. DMP in hybrid and inbred rice varieties under variable doses of phosphorus. Int. J. Sustain. Agric. 2009, 1, 10-19.

29. Fageria, N.; Slaton, N.; Baligar, V. Nutrient Management for Improving Lowland Rice Productivity and Sustainability. Adv. Agron. 2003, 80, 63-152. [CrossRef]

30. Fageria, N.; Baligar, V. Nutrient Availability. In Encyclopedia of Soils in the Environment; Hillel, D., Ed.; Elsevier: San Diego, CA, USA, 2005; pp. 63-71.

31. Yadi, R. Role of zinc fertilizer on grain yield and some qualities parameters in Iranian rice genotypes. Ann. Biol. 2012, 3, 4519-4527.

32. Amanullah; Rahman, H.; Shah, Z.; Shah, P. Effects of plant density and N on growth dynamics, light interception and yield of maize. Arch. Agron. Soil Sci. 2008, 54, 401-411. [CrossRef]

33. Sharma, A.P.; Singh, S.P. Genotypic variation in photosynthesis and yield components in rice. Indian J. Plant Phys. 1994, 37, 188-189.

34. Evans, L.T. The physiological basis of crop yield. In Crop Physiology; Evans, L.T., Ed.; Cambridge University Press: London, UK, 1975.

35. Akinrinde, E.; Gaizer, T. Differences in the Performance and Phosphorus-Use Efficiency of Some Tropical Rice (Oryza sativa L.) Varieties. Pak. J. Nutr. 2006, 5, 206-211. [CrossRef]

36. Wiangsamut, B.; Lafarge, T.A.; Mendoza, T.C.; Pasuquin, E.M. Aagronomic traits and yield components associated with broadcasted and transplanted high-yielding rice genotypes. Crop Prod. 2013, 2, 19-30.

37. Fageria, N.K.; Filho, M.P.B. Dry-Matter and Grain Yield, Nutrient Uptake, and Phosphorus Use-Efficiency of Lowland Rice as Influenced by Phosphorus Fertilization. Commun. Soil Sci. Plant Anal. 2007, 38, 1289-1297. [CrossRef]

38. Fageria, N.K.; Santos, A.B.; Heinemann, A.B. Lowland Rice Genotypes Evaluation for Phosphorus Use Efficiency in Tropical Lowland. J. Plant Nutr. 2011, 34, 1087-1095. [CrossRef]

39. Fageria, N.K.; Dos Santos, A.B.; Cobucci, T. Zinc Nutrition of Lowland Rice. Commun. Soil Sci. Plant Anal. 2011, 42, 1719-1727. [CrossRef]

40. Khan, P.; Memon, M.Y.; Imtiaz, M.; Depar, N.; Aslam, M.; Memon, M.S.; Shah, J.A. Determining the zinc requirements of rice genotype sarshar evolved at NIA Tandojam. Sarhad J. Agric. 2012, 28, 1-7.

41. Rahman, K.M.M.; Chowdhury, M.A.K.; Sharmeen, F.; Sarkar, A.; Hye, M.A.; Biswas, G.C. Effect of zinc and phosphorus on yield of Oryza sativa (cv. br-11). Bangladesh Res. Pub. J. 2011, 5, 351-358.

42. Lal, B.; Majumdar, B.; Venkatesh, M.S. Individual and interactive effects of phosphorus and zinc in lowland rice. Indian J. Hill Farming 2000, 13, 44-46.

43. Tanaka, A.; Osaki, M. Growth and behavior of photosynthesized $14 \mathrm{C}$ in various crops in relation to productivity. Soil Sci. Plant Nutr. 1983, 29, 147-158. [CrossRef]

44. Fageria, N.; Baligar, V.; Clark, R. Root Architecture. In Physiology of Crop Production; The Haworth Press: Binghamton, NY, USA, 2006; pp. 23-59.

45. Foy, C.D. Soil Chemical Factors Limiting Plant Root Growth. Adv. Soil Sci. 1992, 19, 97-149. [CrossRef]

46. Amanullah; Shah, S.; Shah, Z.; Khalil, S.K. Effects of variable nitrogen source and rate on leaf area index and total dry matter accumulation in maize (Zea mays L.) genotypes under calcareous soils. Turk. J. Field Crop. 2014, 19, 276-284. [CrossRef]

47. Epstein, E.; Bloom, A.J. Mineral Nutrition of Plants: Principles and Perspectives; Sinauer Associates, Inc. Publishers: Sunderland, MA, USA, 2005.

48. Peng, S.; Cassman, K.G.; Virmani, S.S.; Sheehy, J.; Khush, G.S. Yield Potential Trends of Tropical Rice since the Release of IR8 and the Challenge of Increasing Rice Yield Potential. Crop. Sci. 1999, 39, 1552-1559. [CrossRef] 
49. Akita, S. Improving yield potential in tropical rice. Prog. Irrig. Rice Res. 1989, 41-73.

50. Amano, T.; Zhu, Q.; Wang, Y.; Inoue, N.; Tanaka, H. Case Studies on High Yields of Paddy Rice in Jiangsu Province, China. I. Characteristics of grain production. Jpn. J. Crop. Sci. 1993, 62, 267-274. [CrossRef] 